\title{
Colonization of Benthic Organisms on Different Artificial Substratum in Ilha Grande Bay, Rio de Janeiro, Brazil
}

\author{
Flávia Beatriz Beserra Azevedo ${ }^{1 *}$, Giuliano Guilherme Carloni ${ }^{2}$ and Lucia Verçosa \\ Carvalheira $^{3}$ \\ ${ }^{1}$ Programa de Pós-Graduação em Ciência Ambiental; Universidade Federal Fluminense; Av. Litorânea, s/n; \\ flaviabbazevedo@vm.uff.br; 24210-340; Niterói - RJ - Brasil. ${ }^{2}$ Ecologus Engenharia Consultiva; Rua do Ouvidor, \\ 60; 20040-030; Rio de Janeiro - RJ - Brasil. ${ }^{3}$ Departamento de Oceanografia e Hidrologia; Universidade do \\ Estado do Rio de Janeiro; Rua. São Francisco Xavier, 524; 20559-900; Rio de Janeiro - RJ - Brasil
}

\begin{abstract}
The aim of this work was to evaluate the influence of three different types of artificial substrates - concrete, metal and rubber - on the colonization of benthic organisms, using a structure called Multiple Disc Sampling Apparatus or MDSA. The results confirmed the hypothesis that the communities of incrusting invertebrates have preferences in relation to the type and orientation of the substratum to be colonized. Concrete and rubber, rougher surfaces, were more attractive to the organisms than the metal used. The orientation also had big influence because of the sedimentation that probably acted on the superior face of the materials, hindered the colonization.
\end{abstract}

Key words: Artificial substrata, colonization, benthic organisms

\section{INTRODUCTION}

The EARRN (The European Artificial Reef Research Network) defines artificial reefs as submerged structures placed deliberately on the seabed, to mimic some characteristics of natural reefs (Baine, 2001). Structures that mimic the characteristics of natural reefs in some fashion, but have other functions, such as piers and the pillars of oil and gas platforms, may be described as secondary artificial reefs (Pickering, et al., 1998).

Marine structures, constructed by men or natural, have a recognized potential to attract and concentrate fish, besides enhancing stocks (Pickering and Whitmarsh, 1997). In the last three decades, structures have been being utilized around the world with many objectives, such as conservation of natural environment, additional habitat to certain species, in aquaculture, in recreational diving, in the rehabilitation and protection of coastal environments (Van Treeck and Schuhmacher, 1999).

The artificial reefs potentially provides substrate for benthic fauna and, therefore, additional food to other organisms; shelter for predation and tidal currents; recruitment habitat for individuals that could be lost from the population; and reduction of harvesting pressure on natural reefs (Pickering and Whitmarsh, 1997). In Ria Formosa, one of the most important estuarine systems of Portugal south coast, after the installation of an artificial reefs system, Santos and Monteiro (1997) observed an enrichment and diversification of the local fish community (including fishes of high commercial value) because the deployment of the structures on a sandy substrate promoted the

\footnotetext{
${ }^{*}$ Author for correspondence
} 
appearance of new benthic communities.

Ships, oil/gas platforms and other structures suffer the action of different physic, chemical and biological marine processes and one of the most important is the biological incrustation. Jacobi and Langevin (1996) sugested that each one of the events of a general process of colonization depended on different substrates complexity, in a way that predicting the colonization patterns required that we appropriate measurement of the relative contribution of each of the characteristics of the substrate. According to Riggio et al. (1985), those kinds of study were valuable in the investigation of the self-organization processes that took place in benthic communities in relation to local environmental factors. The benthic communities are source of food and shelter to many kinds of organisms (Connell, 2001) and have important hole in the subtidal systems. It is important to determine whether the changes in the number of species through time depend on the substratum being colonized and an understanding of these effects on the colonization and development of marine assemblages is interesting when there are so many organisms colonizing the different human-made structures in the sea (Anderson and Underwood, 1994).

The objective of this work was to evaluate the differences in the fixation and colonization of benthic invertebrates in relation to three different types of artificial substratum in the Oil Terminal of Angra dos Reis (TEBIG), a PETROBRAS' terminal of oil transference, situated in Ilha Grande bay, south of Rio de Janeiro state. The work also tested the hypothesis that incrusting invertebrate communities colonize the substratum in different ways in relation to the type of material and orientation of the substratum. The Ilha Grande bay is located in the coordinates $22^{\circ} 50^{\prime} \mathrm{S} / 23^{\circ} 20^{\prime} \mathrm{S}$ and $44^{\circ} 45^{\prime} \mathrm{W} / 44^{\circ} 00^{\prime} \mathrm{W}$ and have approximately $1000 \mathrm{~km} 2$ (Fig. 1). The bay is an estuary partially mixed with the ocean and the circulation is given by the tide effects, winds and density differences (Signorini, 1980). The water temperature is approximately 21.2 to $22.0^{\circ} \mathrm{C}$ and the salinity is 35.0 to 35.5 .

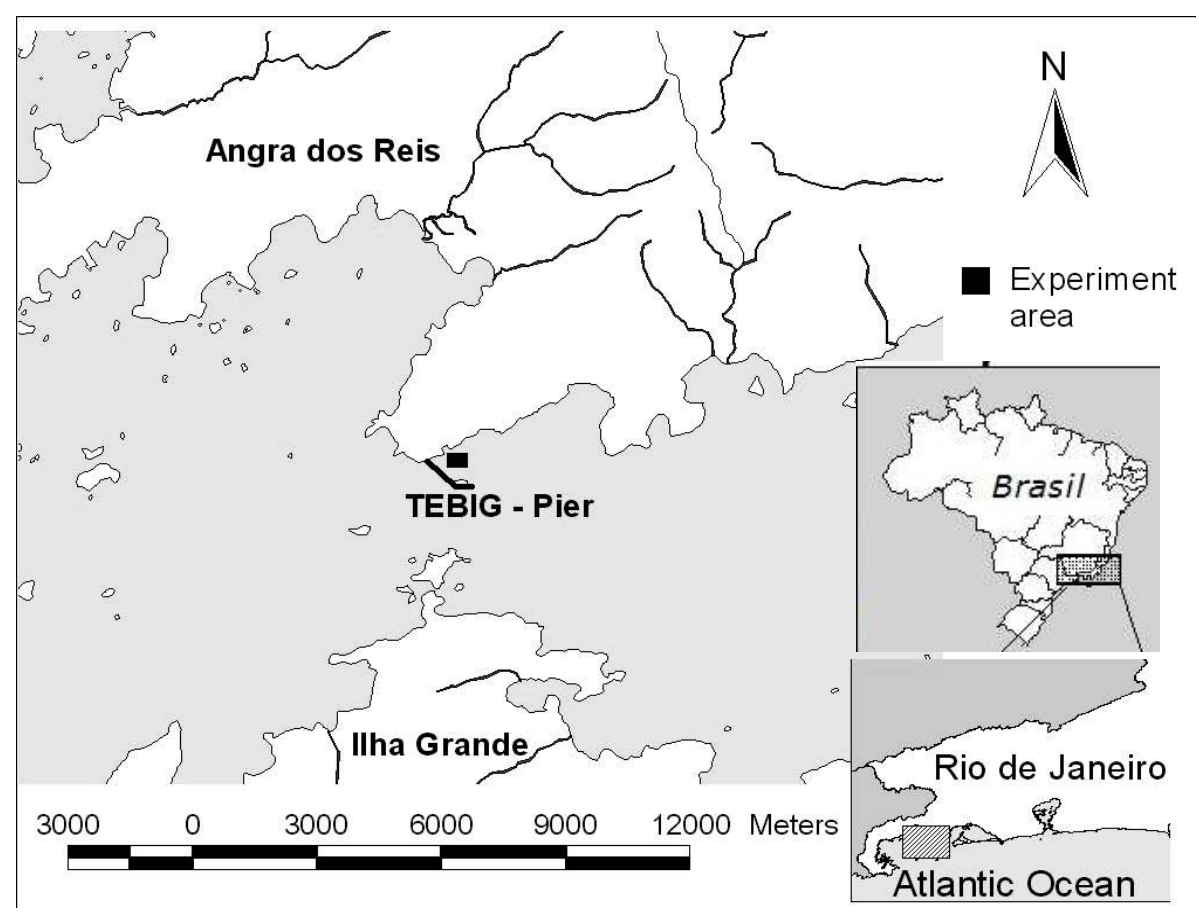

Figure 1 - Localization of Ilha Grande bay, detaching the Oil Terminal of Angra dos Reis (TEBIG).

The Oil Terminal of Angra dos Reis can be considered as a large area of secondary artificial reefs. The pillars that support the pier, the submerged tabulations among other things, and 
even structures that eventually are lost, become substrata to the development of benthic communities and therefore can function such as an artificial reef. Nevertheless, the region has no study about the understanding of how the relation between benthic communities and this variety of available materials is. This work tested the local organisms preference in relation to three different materials: concrete, rubber and metal (galvanized zinc). Theses materials are the most common in the area and the most used in researches with artificial substrates (Anderson and Underwood, 1994, Glasby, 2000, Pearce and Chang, 1982). Some experiments have found that some surface characteristics have factors that influence the number and type of organisms that settle on artificial substratum, such as texture, complexity, size, composition and colour (Glasby, 2000), however, this work has chose to evaluate just the influence of orientation and texture (rugosity) of materials.

\section{MATERIALS AND METHODS}

The artificial structure used to determine the benthic populations preference for the different artificial substrates was based on the structure developed by Pearce and Chang (1982), called Multiple Disc Sampling Apparatus or MDSA. The MDSA consisted of discs of $0.05 \mathrm{~m}^{2}$ (diameter of $24.6 \mathrm{~cm})$, tied on a support with the shape of a table (Fig 2).

Twelve discs of each material with three sample units were made, totaling 36 discs of concrete, 36 discs of rubber and 36 discs of galvanized zinc. Each sample unit consisted in 12 rows of three discs, one of each material. The discs were held by two galvanized zinc wires parallels and fastened to a steel structure. The discs order was not patterned and the rows were put on the structure in a way that discs of the same material were not close. The structures had a table form, measuring $2.85 \mathrm{~m}$ by $1.25 \mathrm{~m}$ and $1 \mathrm{~m}$ height, and weighting approximately 120-130 kg with the discs. Each table foot had cans of $20 \mathrm{~cm}$ height filled with concrete to better support the structures.

The structures were put in June 2002 with the support of a winch and four empty galloons of 50 L tight on each table extremity working as floats. The structures were taken to the submersion site where the ropes were cut down. Using diving equipments the tables were positioned in $6 \mathrm{~m}$ depth, approximately $3 \mathrm{~m}$ far from each other and covering an area of $15 \times 1.5 \mathrm{~m}$ approximately.

During four months, a row of discs were taken from the structures monthly. Each disc was cut from the row, labeled and put in individual bags underwater. At land, each disc was placed in $7.5 \%$ $\mathrm{MgCl}_{2}$ mixed 1:1 with seawater for one hour and then transferred to $10 \%$ formalin (Pearce and Chang, 1982). After $48 \mathrm{~h}$ of fixation the discs were transferred to $70 \%$ ethanol and the species fixed on each type of material were counted by percentage cover (Anderson and Underwood, 1994, Connell, 2001, Maughan, 2001). Percentage cover of both faces of the discs were counted using a plastic ring measuring $22.5 \mathrm{~cm}$ in diameter (400 $\mathrm{cm}^{2}$ in area approximately), with a net of nylon strings with 88 equidistant intersection points.
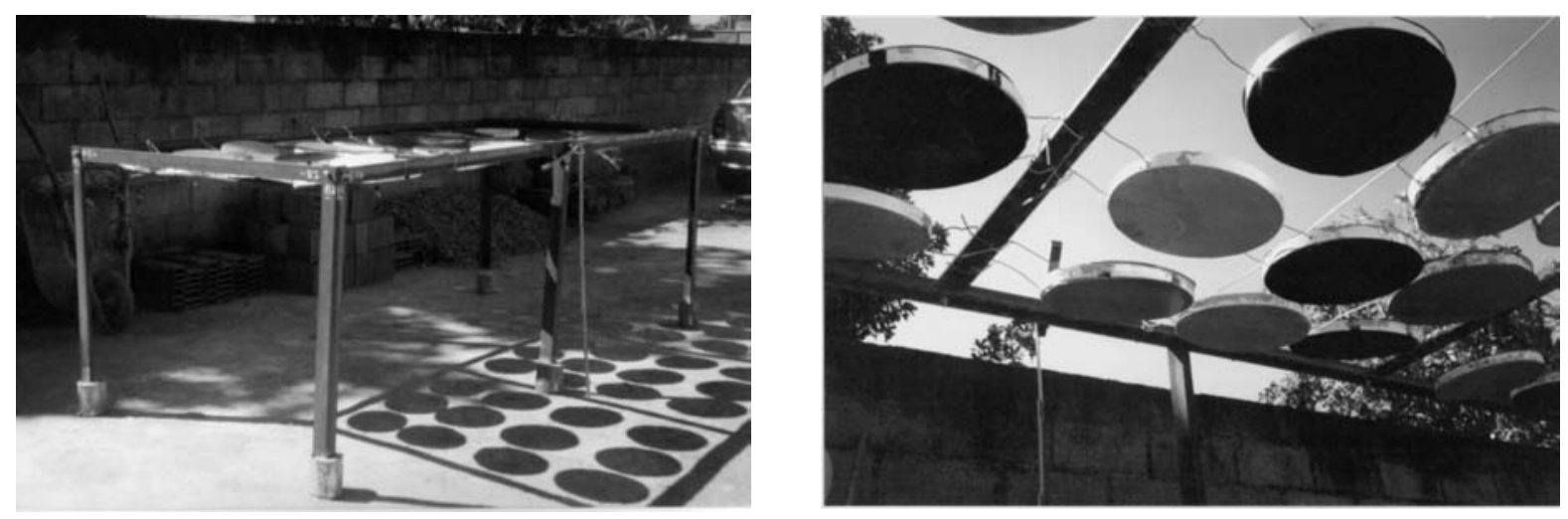

Figure 2 - MDSA elaborated to the experiment. 
The data obtained (the three sample units mean values and standard errors) were used to analyze the benthic community development and composition on each face (upper and under) of each material. The similarity among the communities that colonized the materials through time was analyzed by the Bray-Curtis similarity coefficient and clustering analyze (Legendre and Legendre, 1983, Valentin, 1995). Univariate analyzes were applied through a one-way ANOVA and Tukey test where two factors (substrata $\mathrm{X}$ orientation) were crossed in order to identify important differences among the treatments (Connell, 2001, Glasby, 2000, Maughan, 2001).

\section{RESULTS}

During four months of experiment, seven taxonomic groups of sessile invertebrates were found: Porifera, Hydrozoa, Anthozoa (coral), Annelida (Polychaeta), Crustacea (Cirripedia), Bryozoa, and Ascidiacea. Among them the most variety of species was found in the group of the bryozoans (Fig. 3). Among these groups 15 species were recognized: two sponges, one hydrozoa, one coral, one type of polychaete, seven bryozoans (two encrusting ones and five arborescent ones), two ascidians and one barnacle. Among the barnacles, just once was found an organism sufficiently big to be identified, the others were too young and hence extremely small. All organisms, which were filters, were found only on the under face of the discs where there was no effect of sedimentation and there was little influence of light.

The species richness was crescent during the four months on the under face of the discs of concrete and rubber but the same pattern did not happen on the upper face, where the effect of sedimentation was intense. In a general way, most of the times the species richness was higher on the discs of concrete than on metal, on the lower and upper faces (Figs. 4 and 5).

Through the four months of experiment the most part of the organisms recruited in more quantity on the under face of concrete, except for Nevianipora which had similar percentage cover on concrete and rubber, and the young barnacles which showed preference for the under face of rubber. On the upper face concrete was also the most attractive material to the organisms showing higher values of percentage cover most of the times and having a big percentage of barnacles on the first sampling (first month). However these barnacles did not recruited and occurred again only on sampling 4 (fourth month) but with similar values on concrete and rubber.

Bryozoans showed not only more variety of species but also dominated almost all samplings on the under faces of concrete and rubber being Scrupucellaria cornigera the principal specie responsible for that dominance. This specie had more quantity of organisms on rubber only on the first sampling but showed preference for concrete on the others. Schizoporella sp which showed crescent values of percentage cover during the samplings showed preference for the under face of rubber such as Smittina trispinosa, although this one had also showed great cover on concrete. The other species of bryozoans - Bugula stolonifera, Crisia sp and Bugula neritina - showed preference for the under face of concrete on all samplings that occurred being the first sampling the one with more representative quantities.

The two types of ascidians preferred the under face of concrete alternating the dominance between them along the samplings. The sponges preferred the concrete, while the hydrozoan, which always showed very low quantities, was observed on the under face of the concrete on samplings 1 and 4 (first and fourth months) and on the under face of the rubber on sampling 3 (third month). Tubes of polychaetes containing organisms were found in more quantity on sampling 2 (second month) on the under face of concrete and rubber but preferring this last material. On the other samplings both materials had always many tubes but theses were covered with the encrusting bryozoans.

The clustering analyze (Figs. 6, 7, 8 and 9) showed crescent dissimilarity between under and upper faces of the discs of rubber and concrete through the samplings. Just the disc of metal showed similarity between both faces because there was not colonization by organisms (Figs. 3, 4 and 5). Most of the times both faces of metal were different from the other materials except for sampling 3 when the disc of metal presented small percentage of young barnacles on the upper face such as the upper face of concrete (Figs. 4 and 5). There was high similarity between the under faces of concrete and rubber where all organisms really recruited (Fig. 5). 

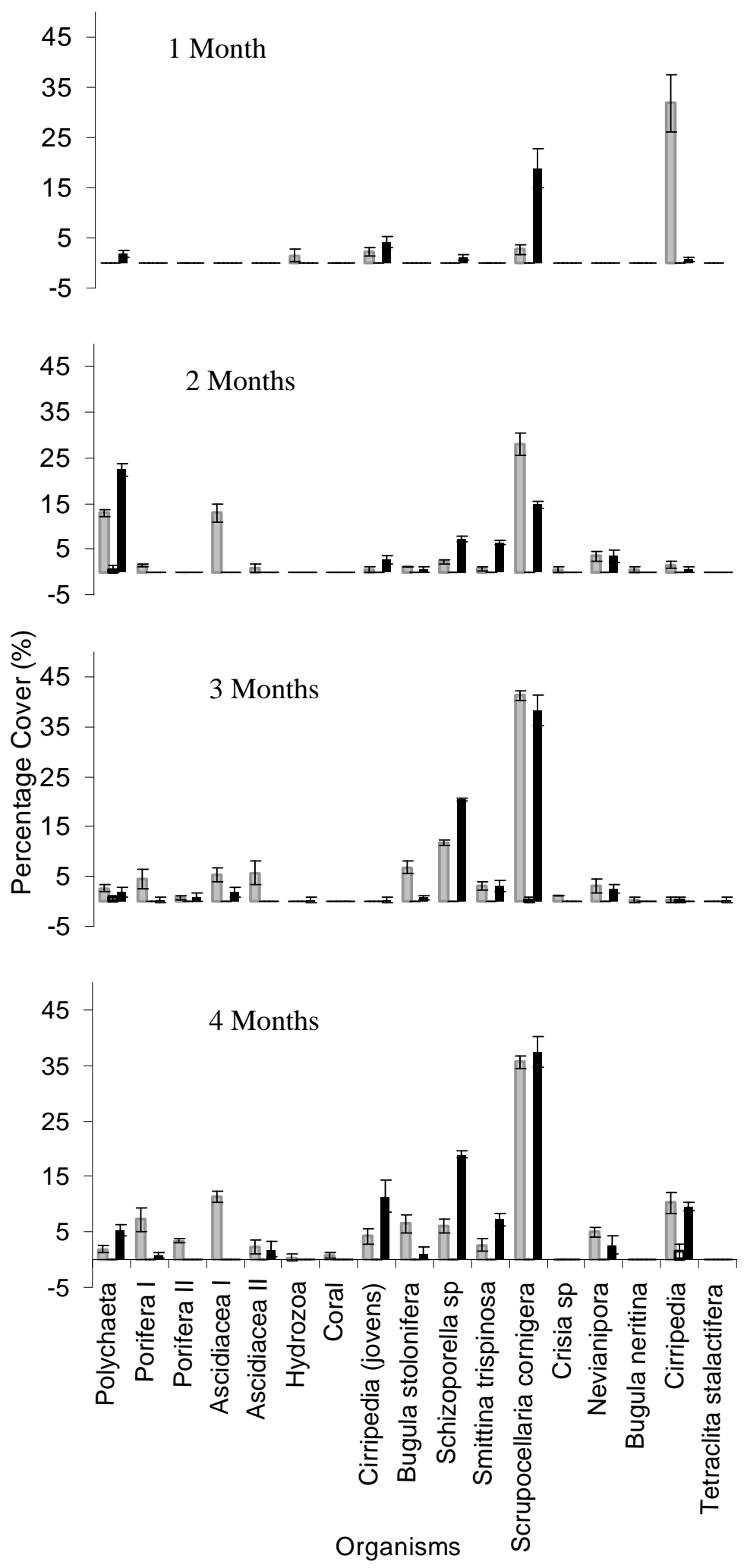

$\square$ Concrete $\square$ Metal $\quad$ Rubber

Figure 3 - Organisms percentage cover (the three sample units mean values \pm standard errors) on the discs on each sampling. 


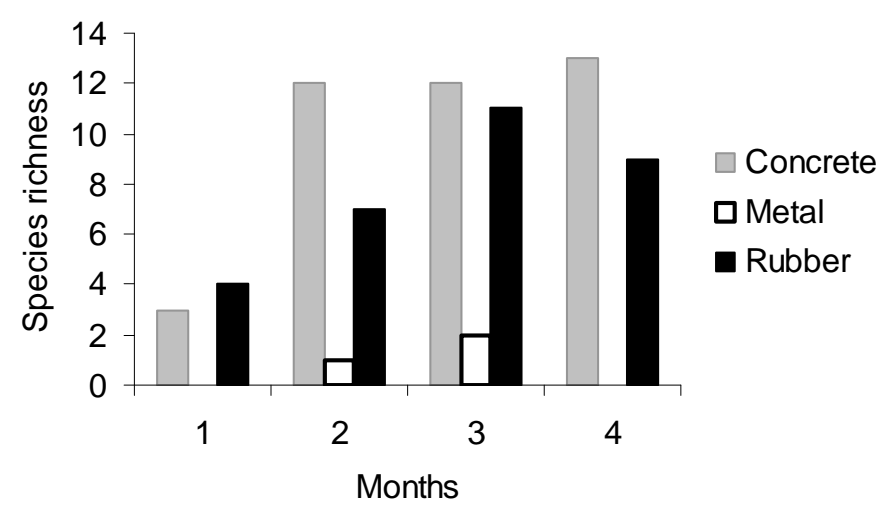

Figure 4 - Species richness on the under face of the discs along the samplings.

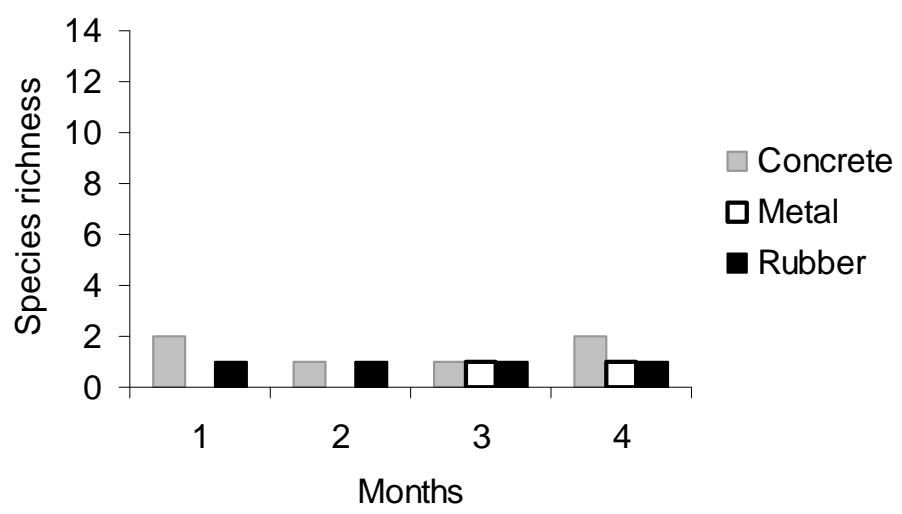

Figure 5 - Species richness on the upper face of the discs along the samplings.

The ANOVA associated with the Tukey test showed that the different treatments had influence in the percentage cover of organisms through the samplings (Tables 1 and 2). The ANOVA was applied to all the organisms groups found but for those which the percentages were too low the analyze showed no influence of treatments. In that way it was difficult to determine if the differences of treatment really did not affected these organisms preference or if the statistic analyze was not able to show such influence because the percentages mean were too small. For that reason only the organisms more representatives were taken into account.

The ANOVA showed that there was difference in the percentage cover of the tested organisms in relation to the material and to the face, except for the barnacles. The young barnacles did not show preferences, being the only organism observed on both faces of concrete and rubber in all samplings (except for the under face of concrete in the third month of sampling) and they also colonized the metal discs (Fig. 3).

With the Tukey test it was possible to identify the differences found by ANOVA. There was not polychaetes on the upper faces of the different materials and it was identified only some tubes on the under faces, except for rubber discs (Fig. 3). The under face of concrete presented values similar to the one of rubber showing interaction between these treatments but the similarities were not enough to differentiate both treatments from the others. 


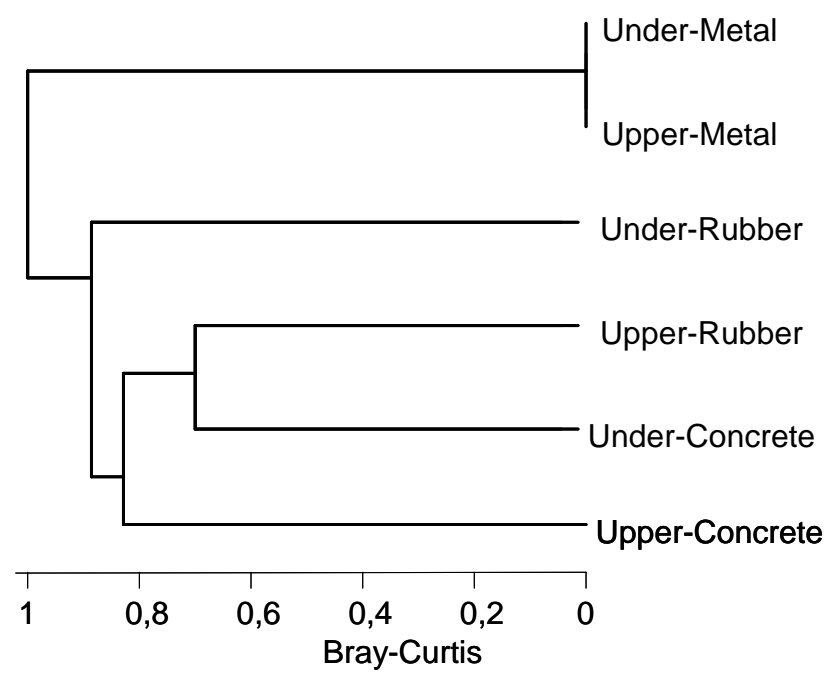

Figure 6 - Clustering analyze for one month of the discs submersion.

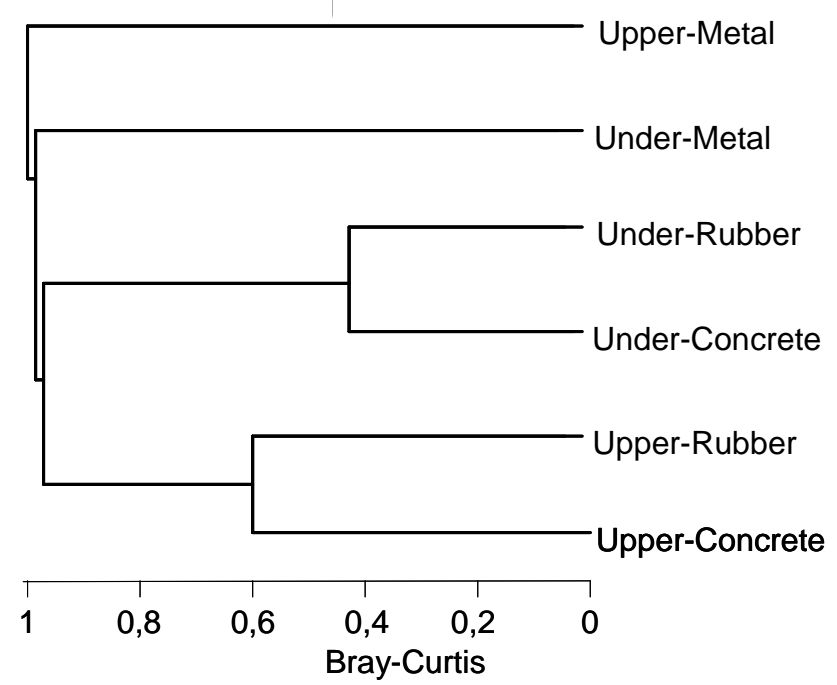

Figure 7 - Clustering analyze for two months of the discs submersion. 


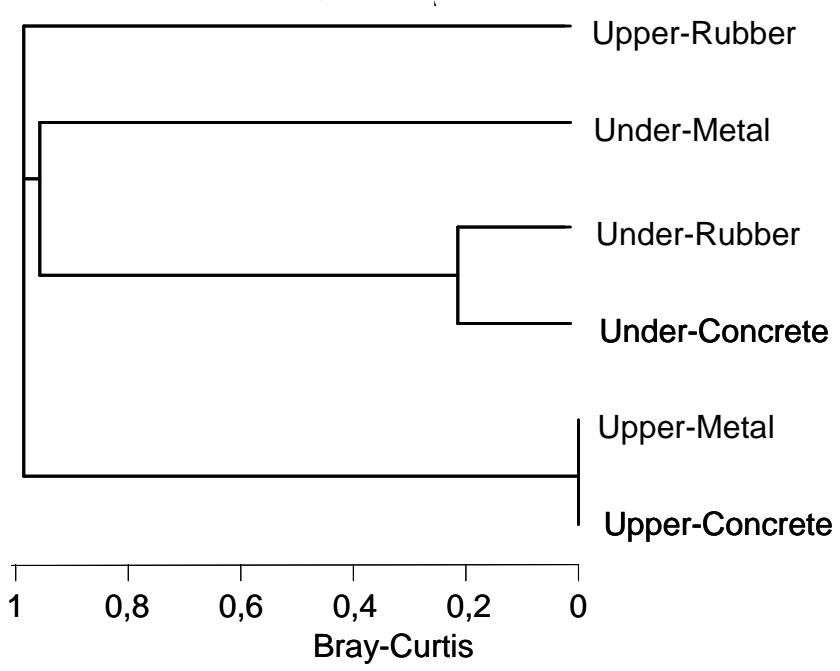

Figure 8 - Clustering analyze for three months of the discs submersion.

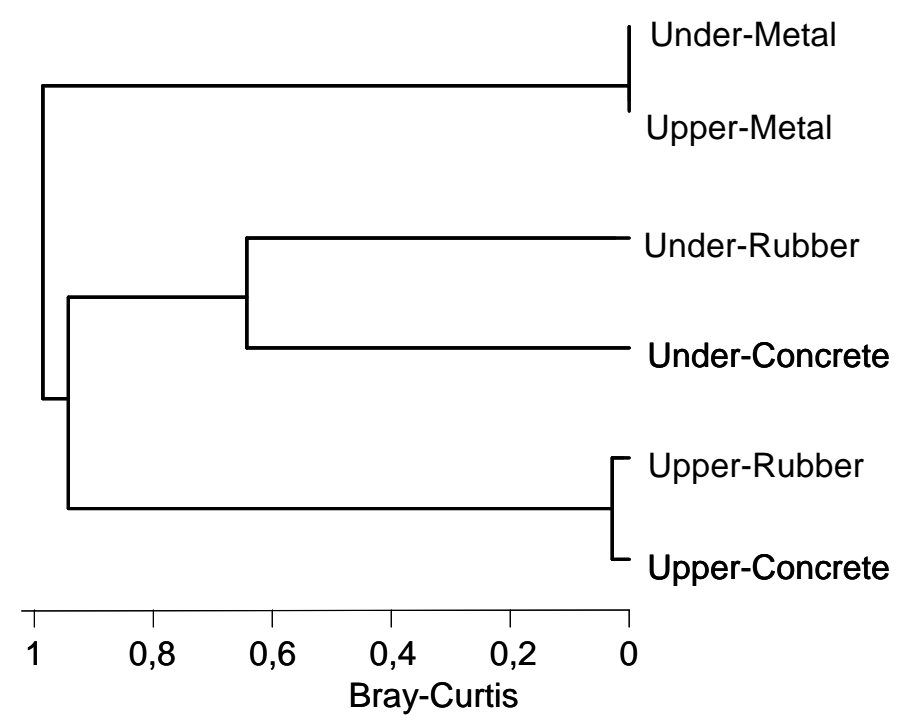

Figure 9 - Clustering analyze for four months of the discs submersion. 
Table 1 - ANOVA comparing the more representatives groups percentage cover in the different treating $(P>0,05)$.

\begin{tabular}{|c|c|c|c|c|}
\hline & df & MS & $\boldsymbol{F}$ & $P$ \\
\hline \multicolumn{5}{|c|}{ Polychaeta } \\
\hline Material & 2 & 86.25 & 3.85 & 0.03 \\
\hline FACE & 1 & 312.50 & 13.95 & 0.00 \\
\hline $\mathrm{M} \times \mathrm{F}$ & 2 & 86.25 & 3.85 & $\mathbf{0 . 0 3}$ \\
\hline \multicolumn{5}{|c|}{ Ascidiacea I } \\
\hline Material & 2 & 102.57 & 9.17 & 0.00 \\
\hline Face & 1 & 123.55 & 11.04 & 0.00 \\
\hline $\mathrm{M} \times \mathrm{F}$ & 2 & 102.57 & 9.17 & 0.00 \\
\hline \multicolumn{5}{|c|}{ Schizoporella sp } \\
\hline Material & 2 & 215.35 & 12.23 & 0.00 \\
\hline Face & 1 & 574.66 & 32.64 & 0.00 \\
\hline $\mathrm{M} \times \mathrm{F}$ & 2 & 215.35 & 12.23 & $\mathbf{0 . 0 0}$ \\
\hline \multicolumn{5}{|c|}{ Scrupocellaria cornigera } \\
\hline Material & 2 & 1472.27 & 8.59 & 0.00 \\
\hline Face & 1 & 5664.67 & 33.05 & $\mathbf{0 . 0 0}$ \\
\hline $\mathrm{M} \times \mathrm{F}$ & 2 & 1404.98 & 8.20 & $\mathbf{0 . 0 0}$ \\
\hline \multicolumn{5}{|c|}{ Cirripedia (jovens) } \\
\hline Material & 2 & 224.85 & 1.59 & 0.21 \\
\hline Face & 1 & 138.89 & 0.99 & 0.32 \\
\hline$M \times F$ & 2 & 234.07 & 1.66 & 0.20 \\
\hline
\end{tabular}

The ascidians of type I preferred the under face of concrete in all samplings they were presented and because of that there was no interaction detected among their treatment and the others (Fig. 3). This specie also occurred on the under face of rubber just once (Fig. 3), that was why this treatment was the only one that did not presented value 1 in the test. Schizoporella sp was observed just on the under face of concrete and rubber but its preference was for the last treatment what differentiated it from the others. Scrupocellaria cornigera occurred in high number on the under faces of concrete and rubber (Fig. 3), that was why these two treatments had good interaction between them but were different in relation to the others. The interactions that presented value 1 , what meant $100 \%$ of interaction and high similarity in relation to the treatment influence on the organisms preference, were that in which the discs did not present organisms on both faces.

The installation of the structures was done in the end of June that consisted of a period of frequent entrance of cold fronts in the region. The structures showed good resistance and remained stable in their positions until the second sampling (August) and, although the great incrustation that rapidly initiated, they showed few signs of corrosion.

In September the Terminal area suffered two weeks of agitated sea because of the action of winds from NE. Although that on the third sampling the structures still showed security but the galvanized wires started to tear more easily when the discs were removed. On the forth sampling, two of the tables had lost some discs. 
Table 2 - Tukey test applied to the groups of organisms that presented differences among the treatments.

\begin{tabular}{|c|c|c|c|c|c|c|}
\hline & $\{1\}$ & $\{2\}$ & $\{3\}$ & $\{4\}$ & $\{5\}$ & $\{6\}$ \\
\hline \multicolumn{7}{|c|}{ Polychaeta } \\
\hline Upper-Concrete $\{1\}$ & & 0.227736 & 1 & 0.999991 & 1 & 0.001841 \\
\hline Under-Concrete $\{2\}$ & 0.227736 & & 0.227736 & 0.296309 & 0.227736 & 0.464501 \\
\hline Upper-Metal $\{3\}$ & 1 & 0.227736 & & 0.999991 & 1 & 0.001841 \\
\hline Under-Metal $\{4\}$ & 0.999991 & 0.296309 & 0.999991 & & 0.999991 & 0.002905 \\
\hline Upper-Rubber $\{5\}$ & 1 & 0.227736 & 1 & 0.999991 & & 0.001841 \\
\hline Under-rubber $\{6\}$ & 0.001841 & 0.464501 & 0.001841 & 0.002905 & 0.001841 & \\
\hline \multicolumn{7}{|c|}{ Ascidiacea I } \\
\hline Upper-Concrete $\{1\}$ & & 0.000141 & 1 & 1 & 1 & 0.999362 \\
\hline Under-Concrete $\{2\}$ & 0.000141 & & 0.000141 & 0.000141 & 0.000141 & 0.000173 \\
\hline Upper-Metal $\{3\}$ & 1 & 0.000141 & & 1 & 1 & 0.999362 \\
\hline Under-Metal $\{4\}$ & 1 & 0.000141 & 1 & & 1 & 0.999362 \\
\hline Upper-Rubber $\{5\}$ & 1 & 0.000141 & 1 & 1 & & 0.999362 \\
\hline Under-rubber $\{6\}$ & 0.999362 & 0.000173 & 0.999362 & 0.999362 & 0.999362 & \\
\hline \multicolumn{7}{|c|}{ Schizoporella sp } \\
\hline Upper-Concrete $\{1\}$ & & 0.05077 & 1 & 1 & 1 & 0.00013 \\
\hline Under-Concrete $\{2\}$ & 0.05077 & & 0.05077 & 0.05077 & 0.05077 & 0.002036 \\
\hline Upper-Metal $\{3\}$ & 1 & 0.05077 & & 1 & 1 & 0.00013 \\
\hline Under-Metal $\{4\}$ & 1 & 0.05077 & 1 & & 1 & 0.00013 \\
\hline Upper-Rubber $\{5\}$ & 1 & 0.05077 & 1 & 1 & & 0.00013 \\
\hline Under-rubber $\{6\}$ & 0.00013 & 0.002036 & 0.00013 & 0.00013 & 0.00013 & \\
\hline \multicolumn{7}{|c|}{ Scrupocellaria cornigera } \\
\hline Upper-Concrete $\{1\}$ & & 0.000242 & 0.999996 & 0.999998 & 0.999996 & 0.000186 \\
\hline Under-Concrete $\{2\}$ & 0.000242 & & 0.000199 & 0.000204 & 0.000199 & 0.999977 \\
\hline Upper-Metal $\{3\}$ & 0.999996 & 0.000199 & & 1 & 1 & 0.000164 \\
\hline Under-Metal $\{4\}$ & 0.999998 & 0.000204 & 1 & & 1 & 0.000167 \\
\hline Upper-Rubber $\{5\}$ & 0.999996 & 0.000199 & 1 & 1 & & 0.000164 \\
\hline Under-rubber $\{6\}$ & 0.000186 & 0.999977 & 0.000164 & 0.000167 & 0.000164 & \\
\hline
\end{tabular}

The metal wire, although galvanized, did not support the effects of corrosion and the tension performed by the discs weight. On the fifth sampling, all the discs from the three structures were lost.

\section{DISCUSSION}

The original structure used by Pearce and Chang (1982) was made by galvanized iron pipes filled with concrete while this work used simple iron bars. This material showed high resistance besides being cheaper and easier to work because the structures were all screwed and so they were easy to transport and set up. The cans filled with 
concrete were also enough to guarantee the stability of the structures at least on an area with the hydrodynamic characteristics as Ilha Grande bay. The only problem was the utilization of the zinc wire that did not resist the discs weight and the corrosion. Two types of Brazilian wire thickness were tested: $\mathrm{n}^{\circ} 14$ and $\mathrm{n}^{\circ} 16$ but this last one, thicker, was difficult to manipulate so the first one was chose. The use of a thicker wire probably would not solve the problem of corrosion but the use of an anode, as used by ships and oil platforms would.

This experiment was able to approach just a period of four months of submersion and it was possible that there was not enough time to a successional process of transition from a community dominated by one or two organisms to another one with more distribution of abundance among more variety of species. However, the results confirmed the hypothesis that the incrusting invertebrate organisms have preferences in relation to the orientation of the substratum to be colonized. In the last decades empirical researches showed that different factors acting in different scales contributed to an initial variation in the colonization and survivor of new colonizers, therefore, influencing the recruiting of adult populations (Navarrete and Wieters, 2000). Glasby (2000) concluded with his works that the composition of a surface associated with its orientation could influence the development of colonization such as the light intensity and the larval behavior could also have important hole. The present work confirmed the action of some of the parameters above.

It could be supposed that the upper face of the discs suffered more sedimentation while the under faces was less exposed to this because of the horizontal orientation and as consequence, few or no organisms recruited over the upper faces of the discs except for the discs of concrete. It is important to emphasize that among the tested materials the concrete is more roughness. With one month of submersion the discs of concrete presented high percentage of young barnacles that probably did not survive because of the intensity of sedimentation. But with four months of submersion, these discs presented again high quantity of these young organisms. On fourth sampling not only concrete but also the discs of rubber and metal presented young barnacles. In this period many algae was also colonizing the surface of the discs in bigger quantities and with bigger sizes. The algae can work as protection to these young recruiters against sedimentation but it could only be confirmed if it was possible to have discs with more time of submersion as barnacles were organisms that colonize continuously and rapidly (Chalmer, 1982).

The bryozoans found colonized just the under face of the discs what was also noted by Glasby (2000). Maughan (2001) confirmed this preference in experiments with light and sedimentation on discs. The author found bryozoans species only on discs affected by no action of light or sediments. During the four months of submersion the bryozoans were dominants on the discs of concrete and rubber which according to Osman and Whitlatch (1995) may occur because some species such as bryozoans offer surfaces that look like not being an habitable substratum for other forms of organisms. However, on the fourth sampling, the dispute for substrate started making this organisms lose space to very young barnacles and polychaetes that colonized even over the incrusting bryozoans (Schizoporella sp e Smittina trispinosa), to the sponges that were each time bigger and to the ascidians that were enhancing their colonies.

Some times colonization on the under faces of the discs of metal was observed and they were represented by tubes of polychaetes and barnacles, the only organisms which colonized this material. About the other materials, the polychaetes preferred rubber in all samplings such as the young barnacles and the incrusting bryozoans Schizoporella sp and Smittina trispinosa. Scrupocellaria cornigera did not present a pattern behavior in relation to a preference. All the other organisms showed preference to concrete as substrate. This pattern was also observed by others (Anderson and Underwood, 1994), where the species preferred concrete and wood but not fiber glass or aluminum. Pearce and Chang (1982) also observed more colonization on discs of concrete and fewer organisms fixed on discs of metal and after some months many organisms were lost because of the corrosion. Other aspect observed by Anderson and Underwood (1994) and Pearce and Chang (1982), also observed in this work, was that the differences of fixation among the different substratum were getting smaller through time at least in relation to the discs of concrete and rubber. The organisms behavior in relation to the colonization of the different substrates can occur in different ways in other experiments because of 
other factors, not only the type of material or the orientation of the substrate. Smith and Rule (2002) sugested that artificial substrates submerged at different periods of the year might be initially occupied by taxa that could more or less affect the recruiting of other taxa. According to Glasby (1999), the position in the water column - if next to bottom or next to the water surface - could also determine the composition of a community such as the size and the shape of the object that was functioning as substrate what could influence the flux of water around it, resulting in different larval supply or fixing rate.

Coastal environments are under crescent pressure as a result of the population enhance. Besides the environmental degradation, this brings another factor that also requires attention: the hole of structures constructed by men as habitats to marine organisms (Connell, 2001). The present work wanted to confirm the differences in colonization on different artificial substrates and not to find their causes. But a better understanding of the differences among these substrates and the natural ones is not only important to the management of coastal ecosystems such as the natural reefs but is also extremely important to know the effects of the continuous addition of theses structures by men to the ecology of coastal habitats.

\section{ACKNOWLEDGEMENTS}

We would like to thank to PETROBRAS for the support in all phases of this work, to FEEMA for the necessary authorization and principally to Dr. Ilana Rozental, from Universidade Estadual do Norte Fluminense, for the indispensable orientation.

\section{RESUMO}

Um terminal de transferência de óleo da PETROBRAS, localizado na baía de Ilha Grande, oferece uma variedade de substratos artificiais para organismos que vivem ou freqüentam a baía. O objetivo deste trabalho foi avaliar a influência de três diferentes tipos de substratos artificiais concreto, metal e borracha - na colonização de organismos bênticos, utilizando uma estrutura denominada Multiple Disc Sampling Apparatus ou MDSA (Aparato de Amostragem de Discos
Múltiplos), que consiste num grupo de discos com $24,6 \mathrm{~cm}$ de diâmetro.Os resultados confirmaram a hipótese de que as comunidades de invertebrados incrustantes têm preferências em relação ao tipo e orientação do substrato a ser colonizado. Concreto e borracha, superfícies mais ásperas, foram mais atrativas aos organismos que o metal utilizado. A orientação também tem grande influência porque a sedimentação, que provavelmente atuou sobre a face superior dos materiais, inibe a colonização.

\section{REFERENCES}

Anderson, M. J. and Underwood, A. J. (1994), Effects of substratum on the recruitment and development of an intertidal estuarine fouling assemblages. Journal of Experimental Marine Biology and Ecology, 184, 217-236.

Baine, M. (2001), Artificial reefs: a review of their design, application, management and performance. Ocean and Coastal Management, 44, 241-259.

Chalmer, P. N. (1982), Settlement patterns of species in a marine fouling community and some mechanisms of succession. Journal of Experimental Marine Biology and Ecology, 58, 73-85.

Connell, S. D. (2001), Urban structure as marine habitats: an experimental comparison of the composition and abundance of subtidal epibiota among pilings, pontoons and rocky reefs. Marine Environmental Research, 52, 115-125.

Glasby, T. M. (1999), Diferences Between Subtidal Epibiota on Pier Pilings and Rocky Reefs at Marinas in Sydney, Australia. Estuarine, Coastal and Shelf Science, 48, 281-290.

Glasby, T. M. (2000), Surface composition and orientation interact to affect subtidal epibiota. Journal of Experimental Marine Biology and Ecology, 248, 177-190.

Jacobi, C. M. and Langevin, R. (1996), Habitat geometry of benthic substrata: effects on arrival and settlement of mobile epifauna. Journal of Experimental Marine Biology and Ecology, 206, 39-54.

Legendre, L. and Legendre, P. (1983), Numerical Ecology. In: Developments in Environmental Modelling, Elsevier, Amsterdam. pp. 419.

Maughan, B. C. (2001), The effects of sedimentation and light on recruitment and development of a temperate, subtidal, epifaunal community. Journal of Experimental Marine Biology and Ecology, 256, 59-71.

Navarrete, S. A. and Wieters, E. A. (2000), Variation in barnacle recruitment over small scales: larval predation by adults and maintenance of community pattern. Journal of Experimental Marine Biology and Ecology, 253, 131-148. 
Osman, R. W. and Whitlatch, R. B. (1995), The influence of resident adults on recruitment: a comparison to settlement. Journal of Experimental Marine Biology and Ecology, 190, 169-198.

Pearce, J. B. and Chang, S. (1982), The Efficacy of Various Materials in Artificial Reef Construction. ICES C. M., 64, 1-15.

Pickering, H. and Whitmarsh, D. (1997), Artificial reefs and fisheries exploitation: a review of the 'attraction versus production' debate, the influence of design and its significance for policy. Fisheries Research, 31, 39-59.

Pickering, H., Whitmarsh, D. and Jensen, A. (1998), Artificial Reefs as a Tool to Aid Rehabilitation of Coastal Ecosystems: Investigation the Potencial. Marine Pollution Bulletin, 37, 505-514.

Riggio, S., Gristina, M., Giaccone, G. and Badalamenti, F. (1985), An eighteen months survey of the artificial reef of Terrassini (N/W Sicily): The invertebrates. OEBALIA, 11, 427-437.

Santos, M. N. and Monteiro, C. C. (1997), The Olhão artificial reef system (south Portugal): Fish assemblages and fishing yield. Fisheries Research, 30, 33-41.

Signorini, S. R. (1980), A Study on the Circulation in Bay of Ilha Grande and Bay of Sepetiba. Part 1, a Survey of the Circulation Based on Experimental Field Data. Bolm. Inst. Oceanogr., 29, 41-55.

Smith, S. D. A. and Rule, M. J. (2002), Artificial substrata in a shallow sublittoral habitat: do they adequately represent natural habitats or the local species pool? Journal of Experimental Marine Biology and Ecology, 277, 25- 41.

Valentin, J. L. (1995), Agrupamento e Ordenação. Oecologia Brasiliensis, 2, 27-55.

Van Treeck, P. and Schuhmacher, H. (1999), Mass Diving Tourism - A New Dimension Calls for New Management Approaches. Marine Pollution Bulletin, 37, 499-504. 